\title{
Journals under Threat: A Joint Response from History of Science, Technology, and Medicine Editors
}

We live in an age of metrics. All around us, things are being standardized, quantified, measured. Scholars concerned with the work of science and technology must regard this as a fascinating and crucial practical, cultural and intellectual phenomenon. Analysis of the roots and meaning of metrics and metrology has been a preoccupation of much of the best work in our field for the past quarter century at least. As practitioners of the interconnected disciplines that make up the field of science studies we understand how significant, contingent and uncertain can be the process of rendering nature and society in grades, classes and numbers.

We now confront a situation in which our own research work is being subjected to putatively precise accountancy by arbitrary and unaccountable agencies. Some may already be aware of the proposed European Reference Index for the Humanities (ERIH), an initiative originating with the European Science Foundation. The ERIH is an attempt to grade journals in the humanities - including "history and philosophy of science". The initiative proposes a league table of academic journals, with premier, second and third divisions. According to the European Science Foundation, ERIH "aims initially to identify, and gain more visibility for, top-quality European Humanities research published in academic journals in, potentially, all European languages". It is hoped "that ERIH will form the backbone of a fully-fledged research information system for the Humanities". What is meant, however, is that ERIH will provide funding bodies and other agencies in Europe and elsewhere with an allegedly exact measure of research quality. In short, if research is published in a premier league journal it will be recognized as first rate; if it appears somewhere in the lower divisions, it will be rated (and not funded) accordingly.

This initiative is entirely defective in conception and execution. Consider the major issues of accountability and transparency. The process of producing the graded list of journals in science studies was overseen by a committee of four (the membership is currently listed at <http://www.esf.org/research-areas/humanities/researchinfrastructures-including-erih/erih-governance-and-panels/erih-expert-panels.html $>$ ). This committee cannot be considered representative. It was not selected in consultation with any of the various disciplinary organizations that currently represent our field such as the European Association for the History of Medicine and Health, the Society for the Social History of Medicine, the British Society for the History of Science, the History of Science Society, the Philosophy of Science Association, the Society for the History of Technology or the Society for Social Studies of Science. Journal editors were only belatedly informed of the process and its relevant criteria or asked to provide any information regarding their publications. No indication has been given 
of the means through which the list was compiled; nor how it might be maintained in the future.

The ERIH depends on a fundamental misunderstanding of conduct and publication of research in our field, and in the humanities in general. Journals' quality cannot be separated from their contents and their review processes. Great research may be published anywhere and in any language. Truly ground-breaking work may be more likely to appear from marginal, dissident or unexpected sources, rather than from a well-established and entrenched mainstream. Our journals are various, heterogeneous and distinct. Some are aimed at a broad, general and international readership, others are more specialized in their content and implied audience. Their scope and readership say nothing about the quality of their intellectual content. The ERIH, on the other hand, confuses internationality with quality in a way that is particularly prejudicial to specialist and non-English language journals. In a recent report, the British Academy, with judicious understatement, concludes that "the European Reference Index for the Humanities as presently conceived does not represent a reliable way in which metrics of peer-reviewed publications can be constructed" (Peer Review: the Challenges for the Humanities and Social Sciences, September 2007: $<$ http://www.britac.ac.uk/reports/peer-review $>$ ). Such exercises as ERIH can become self-fulfilling prophecies. If such measures as ERIH are adopted as metrics by funding and other agencies, then many in our field will conclude that they have little choice other than to limit their publications to journals in the premier division. We will sustain fewer journals, much less diversity and impoverish our discipline.

Along with many others in our field, this journal has concluded that we want no part of this dangerous and misguided exercise. This joint Editorial is being published in journals across the fields of history of science and science studies as an expression of our collective dissent and our refusal to allow our field to be managed and appraised in this fashion. We have asked the compilers of the ERIH to remove our journals' titles from their lists.

Hanne Andersen (Centaurus)

Roger Ariew \& Moti Feingold (Perspectives on Science)

A. K. BAG (Indian Journal of History of Science)

June Barrow-Green \& Benno van Dalen (Historia Mathematica)

Keith Benson (History and Philosophy of the Life Sciences)

Marco Beretta (Nuncius)

Michel Blay (Revue d'Histoire des Sciences)

JOHANA BLEKer (Medizinhiztorisches Journal)

CORnelius BORCK (Berichte zur Wissenschaftsgeschichte)

Geof Bowker \& Susan Leigh Star (Science, Technology and Human Values)

Massimo Bucciantini \& Michele Camerota (Galilaeana: Journal of Galilean Studies)

Jed Buchwald \& Jeremy Gray (Archive for History of Exact Sciences) 
Vincenzo Cappelletti \& Guido Cimino (Physis)

Cathryn Carson (Historical Studies in the Natural Sciences)

Mark Clark \& Alex Keller (ICON)

Roger Cline (International Journal for the History of Engineering \& Technology)

Stephen Clucas \& Stephen Gaukroger (Intellectual History Review)

Hal Cook \& Anne Hardy (Medical History)

Leo Corry, Alexandre Métraux \& Jürgen Renn (Science in Context)

Brian Dolan \& Bill Luckin (Social History of Medicine)

Hilmar Duerbeck \& Wayne Orchiston (Journal of Astronomical History \& Heritage)

Moritz Epple, Mikael HÅrd, Hans-Jörg Rheinberger \& Volker Roelcke (NTM:

Zeitschrift für Geschichte der Wissenschaften, Technik und Medizin)

Paul Farber (Journal of the History of Biology)

Mary Fissell \& Randall Packard (Bulletin of the History of Medicine)

Robert Fox (Notes \& Records of the Royal Society)

Marina Frasca Spada (Studies in History and Philosophy of Science)

Steven French (Metascience)

Jim Good (History of the Human Sciences)

Willem Hackmann (Bulletin of the Scientific Instrument Society)

Robert Hallieux (Archives Internationales d'Histoire des Sciences)

Bosse Holmevist (Lychnos)

Rod Home (Historical Records of Australian Science)

Michael Hoskin (Journal for the History of Astronomy)

IAN INKSTER (History of Technology)

Nick Jardine (Studies in History and Philosophy of Biological and Biomedical Sciences)

Trevor Levere (Annals of Science)

Bernard Lightman (Isis)

Christoph Lüthy (Early Science and Medicine)

Michael Lynch (Social Studies of Science)

Stephen McCluskey \& Clive Ruggles (Archaeostronomy: The Journal of Astronomy in Culture)

Peter Morris (Ambix)

Iwan Rhys Morus (History of Science)

E. Charles Nelson (Archives of Natural History)

Ian Nicholson (Journal of the History of the Behavioural Sciences)

Kathy Olesko (Osiris)

Liliane Pérez (Documents pour l'Histoire des Techniques)

John Rigden \& Roger H Stuewer (Physics in Perspective)

Julio SAmsó (Suhayl: Journal for the History of the Exact and Natural Sciences in Islamic Civilisation)

Simon Schaffer (British Journal for the History of Science)

Norbert Schappacher (Revue d'Histoire des Mathématiques) 
4 Journals under Threat: A Joint Response

John Staudenmaier SJ (Technology and Culture)

Claire Strom (Agricultural History)

Paul Unschuld (Sudhoffs Archiv)

Peter Weingart (Minerva)

Stefan Zamecki (Kwartalnik Historii Nauki i Techniki)

Huib ZuidervaArt (Studium: Tijdschrift voor Wetenschaps- en Universiteitgeschiedenis/ Revue de l'Histoire des Sciences et des Universités) 